\title{
BUSINESS STUDENTS' CAREER INTEREST IN ACCOUNTING PROFESSION: AN EXPLORATORY STUDY IN TURKEY
}

\author{
Mahmut Yardımcıŏlu ${ }^{1}$, Şebnem $\mathrm{Ada}^{2}$ \\ ${ }^{1}$ Kahramanmaraş Sütçü Imam University, School of Economics and Administrative Sciences, Department of \\ Business Administration, Kahramanmaraş, TURKEY \\ mahmutyardimcioglu@gmail.com \\ ${ }^{2}$ Selçuk University, Beyşehir A. A. Vocational School, Department of Accounting and Tax Practices, Beyşehir, \\ Konya, TURKEY (Corresponding Author) \\ sebnemtez@hotmail.com
}

\begin{abstract}
Accounting is a very important profession in today's contemporary business environment. On the other hand, it is also becoming more difficult to find qualified graduates specialized in accounting. Therefore, in order to foster students to be interested in accounting, it is of utmost importance to identify the factors that determine students' interest in this field. This study identifies and investigates the factors (i.e., career outcome expectation, career challenge, social influence, and academic performance in accounting) that are likely to influence students' career interests in the field of accounting. A structured survey was administered to university students located in a province in Turkey. The findings of this research study reveal that students that aim to pursue a challenging career; that are influenced by other people related to their career decisions; and that have greater academic performance in accounting will be interested in pursuing a career in the field of accounting.
\end{abstract}

\section{Indexing terms/Keywords}

Accounting, career interest, career outcome expectation, career challenge, social influence, academic performance

\section{Business Administration; Accounting \\ SUBJECT CLASSIFICATION \\ Social Science}

Academic Discipline And Sub-Disciplines

TYPE (METHOD/APPROACH)

Empirical research; Survey/Interview

\section{Council for Innovative Research}

\section{Peer Review Research Publishing System}

\section{Journal: Journal of Social Sciences Research}

\author{
Vol. 8, No.3 \\ jssreditor.cir@gmail.com
}

www.jssronline.com 


\section{INTRODUCTION}

Accounting profession is of great importance in today's contemporary business environment. The need for the qualified people specialized in this field is on the increase as well. However, the quality and/or quantity of students that major or willing to major in accounting and pursue a career in this field has been an important concern for decades (Tan and Laswad, 2006; Jackling et al., 2012). The challenging nature of the accounting practices (e.g., client environment, technology, financial instruments, globalization, etc.) (Byrne and Willis, 2005), challenging requirements to complete a degree in accounting or to become an accountant (Allen, 2004) make it difficult to appeal high quality students to pursue a career and to be interested in the accounting field. Therefore, in order to foster students to be interested in accounting, it is of utmost importance to identify the factors that determine students' interest in this field.

There are a number of studies with respect to the accounting profession in the literature; and these studies investigate the subject from different perspectives. Literature on this subject can be categorized into three themes: career choice, career intention, and career interest in accounting. Literature reveals that several factors, such as interest (Bolhan et al., 2007; Heiat et al., 2007), parental influence (Auyeung and Sands, 1997; Bolhan et al., 2007), peer influence (Auyeung and Sands, 1997; Bolhan et al., 2007), teacher influence (Auyeung and Sands, 1997), and financial factors (Ahmed et al., 1997; Heiat et al., 2007), positively influence the career choice of students towards accounting. Another theme of research on accounting profession focused on students' career intentions. Studies found that positive attitudes and subjective noms (Churchman, 2013), personal perception and important referents (Tan and Laswad, 2006), and accounting educators (Jackling and Calero, 2006) have positive impact on students' career intentions with respect to the accounting profession. Finally, studies in the literature also put emphasis on the career interest in accounting profession. These studies investigated how attitudes (Jackling et al., 2012), image (Mc Dowall et al., 2012), race (Yang et al., 2012), values (Baker, 1976), other factors (e.g., job opportunities and income) (Hutaibat, 2012) influence students' career interest in accounting. Table 1 summarizes the studies in the literature that focused on the accounting profession.

Table 1. Summary of studies related to accounting profession

\begin{tabular}{|c|c|c|c|}
\hline Author(s) & Theme & Location & Findings \\
\hline $\begin{array}{l}\text { Churchman } \\
\text { (2013) }\end{array}$ & Career intention & United States & $\begin{array}{l}\text { undergraduate students' positive attitudes toward the } \\
\text { accounting proffession and subjective noms } \\
\text { (referents) are the important factors that affect the } \\
\text { students' intention to enter the profession. }\end{array}$ \\
\hline Hutaibat (2012) & Career interest & Jordan & $\begin{array}{l}\text { job opportunities and income play important roles for } \\
\text { students to prefer public accounting rather than } \\
\text { management accounting. }\end{array}$ \\
\hline $\begin{array}{l}\text { Jackling et al. } \\
(2012)\end{array}$ & Career interest & Australia & $\begin{array}{l}\text { students have positive attitudes towards the } \\
\text { accounting profession. }\end{array}$ \\
\hline $\begin{array}{l}\text { Mc Dowall et al. } \\
(2012)\end{array}$ & Career interest & Australia & $\begin{array}{l}\text { there is a negative image on accountants; and } \\
\text { students find accounting profession boring and } \\
\text { precise. }\end{array}$ \\
\hline $\begin{array}{l}\text { Yang et al. } \\
(2012)\end{array}$ & Career interest & United States & $\begin{array}{l}\text { African-American students have greater accounting } \\
\text { career interests than Caucasian students, before and } \\
\text { after controlling for the impact of math performance } \\
\text { and gender. }\end{array}$ \\
\hline $\begin{array}{l}\text { Bolhan et al. } \\
\text { (2007) }\end{array}$ & Career choice & Malaysia & $\begin{array}{l}\text { self interest, parents' advice, and friends/peers affect } \\
\text { students'choice in accounting profession. }\end{array}$ \\
\hline $\begin{array}{l}\text { Heiat et al. } \\
(2007)\end{array}$ & Career choice & United States & $\begin{array}{l}\text { genuine interest in the subject, availability of } \\
\text { employment, and starting pay are the factors } \\
\text { impacting the choice. }\end{array}$ \\
\hline $\begin{array}{l}\text { Jackling and } \\
\text { Calero (2006) }\end{array}$ & Career intention & Australia & $\begin{array}{l}\text { accounting educators have an important role in } \\
\text { determining students' intention to become an } \\
\text { accountant. }\end{array}$ \\
\hline $\begin{array}{l}\text { Tan and Laswad } \\
(2006)\end{array}$ & Career intention & New Zealand & $\begin{array}{l}\text { The following factors affect students' intention to } \\
\text { major in accounting and non-accounting disciplines: } \\
\text { personal perception about the accounting profession, } \\
\text { important referents, interest in accounting, required } \\
\text { workload, and job opportunities. }\end{array}$ \\
\hline
\end{tabular}




\begin{tabular}{|l|l|l|l|}
\hline Allen (2004) & Career choice & United States & $\begin{array}{l}\text { 150-hour accounting course requirement negatively } \\
\text { influence students. }\end{array}$ \\
\hline $\begin{array}{l}\text { Pritchard et al. } \\
(2004)\end{array}$ & Career choice & United States & $\begin{array}{l}\text { business students who have quantitative skills tend to } \\
\text { major in accounting and finance. }\end{array}$ \\
\hline $\begin{array}{l}\text { Ahmed et al. } \\
(1997)\end{array}$ & Career choice & New Zealand & $\begin{array}{l}\text { financial and job-related factors differentiate } \\
\text { accounting and nonaccounting students }\end{array}$ \\
\hline $\begin{array}{l}\text { Suyeung and } \\
\text { Sands (1997) }\end{array}$ & Career choice & $\begin{array}{l}\text { Australia, Hong } \\
\text { Kong, and } \\
\text { Taiwan }\end{array}$ & $\begin{array}{l}\text { parental influence, peer influence, teacher influence, } \\
\text { and association with others in the field have greater } \\
\text { impact on Hong Kong and Taiwanese students; and } \\
\text { aptitude by subject matter have greater impact on } \\
\text { Australian students. }\end{array}$ \\
\hline $\begin{array}{l}\text { Lowe and } \\
\text { Simons (1997) }\end{array}$ & Career choice & United States & $\begin{array}{l}\text { future earnings and career options are the most } \\
\text { important influential factors }\end{array}$ \\
\hline $\begin{array}{l}\text { Felton et al. } \\
(1995)\end{array}$ & Career choice & Canada & $\begin{array}{l}\text { accounting and finance students have more tendency } \\
\text { to become a chartered accountant }\end{array}$ \\
\hline Baker (1976) & Career interest & United States & $\begin{array}{l}\text { accounting students prefer the value of "comfortable } \\
\text { life" more, as compared to non-accounting majors. }\end{array}$ \\
\hline
\end{tabular}

The objective of this study is to identify the factors that determine students' interest in the field of accounting. In order to do this, the current study develops a research model by identifying the factors (i.e., career outcome expectation, career challenge, social influence, and academic performance in accounting) that are likely to influence students' career interests in the field of accounting. In the context of this study, a structured survey was administered in a state university in Turke $y$. The hypotheses mentioned in the research model were tested by the partial least squares (PLS) method through the use of SmartPLS software package (Version 2.0.M3) (Ringle, Wende, \& Will, 2005).

The remainder of the paper is organized as follows. The next section presents the research model and rationale for the hypotheses tested in the context of this study. Section 3 details the research methodology, data collection as well as data analysis procedures. Section 4 presents the findings of the study. The final section is devoted to the conclusions.

\section{HYPOTHESIS DEVELOPMENT}

In this study, we are examining the impact of several factors (i.e., career outcome expectation, career challenge, social influence, and academic performance in accounting) on the career interests of business administration students in the field of accounting. Figure 1 illustrates the research model and hypotheses developed for this study.

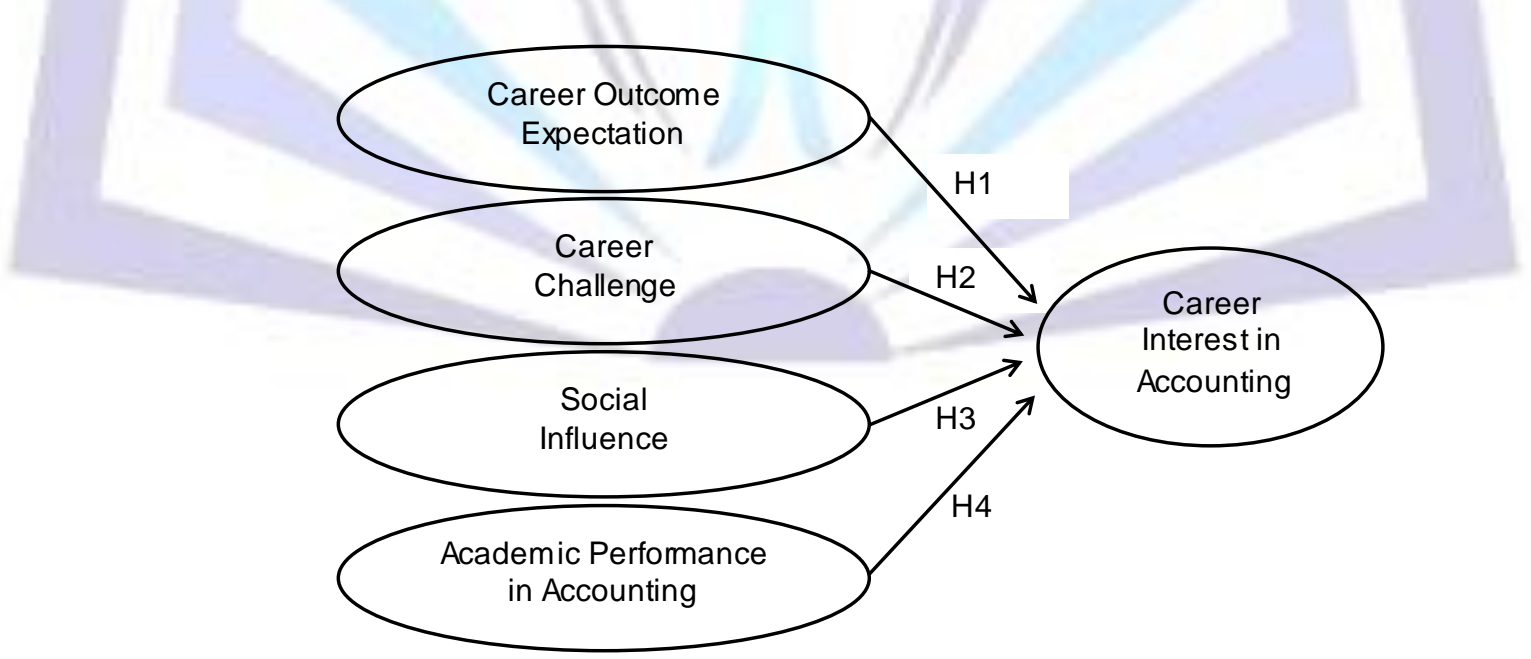

Figure 1. Research model

One of the most important factors that is likely to influence students' interest in a certain career field is their outcome expectation. Outcome expectation is defined by Bandura (1997) as the belief that a certain behavior will lead to a particular outcome that is observed in physical, social, and self-evaluative forms. Bandura (1986) stresses that people form enduring interest in an activity, if they perceive that they are competent in it and if they expect that it will produce 
valuable outcomes. This is also true in career context. If a student expects that a career field is promising and likely to provide opportunities in the future, s/he will be likely to be interested in that specific field.

The prior research also provide evidence to support this. The findings of Lent et al. (1996) reveal that students' academic and career interests are strongly related to career outcome expectation. In line with this argument, we suggest that students with greater expectations from their career field, they will be more likely to pursue a career in accounting. That is, if a student would like to have broader exposure to business, more job opportunities, and higher future earnings and advancement potential, s/he will be more likely to be interested in a career in the field of accounting. Thus, we propose the following hypothesis:

\section{Hypothesis 1: Career outcome expectation is positively related to career interest in accounting.}

Another factor that may enable students to pursue a career in accounting is the challenge that it possesses (Felton et al., 1994; Ahmed et al., 1997). Put another way, if a student likes to work in challenging conditions, it is greatly likely that the student become interested in accounting. The findings of the previous research studies indicate that workload and number oriented nature of the accounting field negatively influences students' career decisions in accounting (Cohen and Hanno, 1993; Saemann and Crooker, 1999; Allen, 2004). We argue that opposite of this argument is legitimate as well, as students preferring challenging working conditions, including working with a lot of numbers and heavy workload, will have tendency to pursue a career in the field of accounting. Thus, we propose the following:

\section{Hypothesis 2: Career challenge is positively related to career interest in accounting.}

Social influence is proposed as another factor that have an impact on career interest of students. We define social influence as the perceived social pressure with respect to perform or not to perform a behavior (Ajzen, 1991; Fishbein and Ajzen, 1975). People usually behave in a certain way due to the suggestions by important others. This is same in career context, as students may become interested in a certain field based on the influence of other people.

The prior research also states that career related decisions of students are influenced by important others (Silverstone and Williams, 1979; Paolillo and Estes, 1982; Inman et al., 1989; Lowe and Simons, 1997; Mauldin et al., 2000). In parallel with the prior literature, we argue that students' career interest in the field of accounting is affected by other people including parents, relatives, peers, teachers, and business people. Therefore, we propose the following hypothes is:

Hypothesis 3: Social influence is positively related to career interest in accounting.

Finally, we propose that students receiving higher grades in accounting course will have higher motivation to pursue a career in accounting. The prior studies also mention that students' career decisions in accounting field is impacted by their performance in accounting courses they took in the university (Felton et al., 1994; Ahmed et al., 1997). Therefore, we propose:

Hypothesis 4: Academic performance in accounting is positively related to career interest in accounting.

\section{RESEARCH METHODOLOGY Variables and Measures}

The research model presented in this study includes four independent variables (career outcome expectation, career challenge, social influence, academic performance in accounting) and one dependent variable (career interest in accounting). The survey method was used to measure the variables in the research model. The measurement items used in the present research were adapted or created based on the prior literature. Table 2 shows the research variables, their definitions, and the literature sources used to develop the measurement items.

Table 2. Variables, number of items, and sources

\begin{tabular}{|l|c|l|}
\hline \multicolumn{1}{|c|}{ Variable } & $\begin{array}{l}\text { Number of } \\
\text { Items }\end{array}$ & \multicolumn{1}{|c|}{ Source } \\
\hline Career Outcome Expectation (COE) & 4 & $\begin{array}{l}\text { Tan and Laswad (2006) } \\
\text { Ahmed et al. (1997) } \\
\text { Lowe and Simons (1997) } \\
\text { Felton et al. (1995) }\end{array}$ \\
\hline Career Challenge (CC) & 3 & $\begin{array}{l}\text { Tan and Laswad (2006) } \\
\text { Ahmed et al. (1997) } \\
\text { Mauldin et al. (2000) } \\
\text { Lowe and Simons (1997) }\end{array}$ \\
\hline Social Influence (SI) & 4 & $\begin{array}{l}\text { Byrne and Willis (2005) } \\
\text { Allen (2004) } \\
\text { Auyeung and Sands (1997) } \\
\text { Lowe and Simons (1997) }\end{array}$ \\
\hline Academic Perfomance in Accounting (AP) & 1 & $\begin{array}{l}\text { Allen (2004) } \\
\text { Ahmed et al. (1997) }\end{array}$ \\
\hline Career Interest in Accounting (CI) & 10 & $\begin{array}{l}\text { Chai (2009) } \\
\text { Schaffner and Jepsen, 1999 } \\
\text { Lent et al. (1994) }\end{array}$ \\
\hline
\end{tabular}




\section{Data Collection}

To test the research hypotheses, a structured survey was administered in Spring 2013 to business administration students in a state university in Turkey. The survey was composed of two sections: (1) questions measuring the research constructs and (2) demographic questions (gender, year of the education, type of the education). Two hundred and fifty students participated in the survey and all of the surveys were used in the final data analysis.

$56 \%(N=141)$ of the survey responders were female $(N=141)$, whereas $44 \%$ percent $(N=109)$ were male. The majority of the sample (56\%) was composed of freshmen students $(N=140)$, while $36.8 \%$ was sophomore $(N=92), 6.8 \%$ was junior $(N=17)$, and $0.4 \%$ was senior $(N=1)$ students. In addition, $45 \%$ of the students $(N=113)$ participated in the survey were attending nomal education program and $55 \%$ of the students $(N=137)$ were attending evening education program.

\section{Data Analysis}

Structural Equation Modeling (SEM) was used to test the measurement and structural models. To evaluate the psychometric properties of the measurement scales and to test the research hypotheses presented in Figure 1, the component-based partial least squares (PLS) approach was us ed. The SmartPLS software package (Version 2.0.M3) was used to estimate the parameters of the research model (Ringle, Wende, \& Will, 2005).

The analysis of the measurement model indicates that AVE (average variance extracted) and Cronbach's alpha values for each variable are at the acceptable level. This indicates that our constructs have adequate reliability assessment. Table 3 reports the results of testing the discriminant validity of the measure scales. Discriminant validity of the scales is supported because the bolded elements (square roots of AVEs) in the matrix diagonals are greater in all cases than the off-diagonal elements in their corresponding row and column.

Table 3. Discriminant validity and construct correlations

\begin{tabular}{|l|l|l|l|l|l|}
\hline & CE & CC & SI & AP & CI \\
\hline Career Outcome Expectation (COE) & $\mathbf{0 . 7 5}$ & & & & \\
\hline Career Challenge (CC) & 0.31 & $\mathbf{0 . 6 9}$ & & & \\
\hline Social Influence (SI) & 0.12 & 0.18 & $\mathbf{0 . 7 1}$ & & \\
\hline Academic Perfomance in Accounting (AP) & -0.07 & 0.19 & 0.01 & $\mathbf{1 . 0 0}$ & \\
\hline Career Interest in Accounting (CI) & 0.11 & 0.44 & 0.26 & 0.34 & $\mathbf{0 . 8 1}$ \\
\hline
\end{tabular}

The results of testing the convergent validity of the measurement scales are reported in Table 4 . Convergent validity was tested using SmartPLS by extracting the factor loadings and cross loadings of all the measurement items to their respective constructs. The results reveal that all of the measurement item loadings on the intended constructs a re at the acceptable level. In addition, each item's factor loading on its respective construct is highly significant $(p<0.001)$. Therefore, the loadings presented in Table 3 confirm the convergent validity of the measures for research constructs.

Table 4. Item loadings, cross-loadings, means, and standard deviations

\begin{tabular}{|c|c|c|c|c|c|c|c|}
\hline & CE & $\mathrm{CC}$ & SI & AP & $\mathrm{Cl}$ & Mean & $\begin{array}{l}\text { St. } \\
\text { Dev. }\end{array}$ \\
\hline \multicolumn{8}{|l|}{$\begin{array}{l}\text { CAREER OUTCOME EXPECTATION (CE) } \\
\text { I would like to pursue a career with... }\end{array}$} \\
\hline ...broad exposure to business. & 0.95 & 0.33 & 0.13 & -0.07 & 0.13 & 4.24 & 0.89 \\
\hline ...high future earnings potential. & 0.78 & 0.20 & 0.07 & -0.07 & 0.05 & 4.30 & 0.87 \\
\hline ...more job opportunities. & 0.59 & 0.13 & 0.06 & 0.01 & 0.03 & 4.28 & 0.95 \\
\hline ...high advancement potential. & 0.62 & 0.17 & 0.06 & -0.06 & 0.01 & 4.46 & 0.81 \\
\hline \multicolumn{8}{|l|}{$\begin{array}{l}\text { CAREER CHALLENGE (CC) } \\
\text { I would like to pursue a career that... }\end{array}$} \\
\hline ...is closely related to numbers. & 0.21 & 0.85 & 0.17 & 0.21 & 0.44 & 3.19 & 1.22 \\
\hline ...is challenging. & 0.35 & 0.57 & 0.12 & 0.04 & 0.19 & 3.38 & 1.15 \\
\hline ...demands a heavy workload. & 0.16 & 0.63 & 0.05 & 0.07 & 0.20 & 2.92 & 1.12 \\
\hline \multicolumn{8}{|l|}{$\begin{array}{l}\text { SOCIAL INFLUENCE (SI) } \\
\text { Regarding my career, I am influenced by... }\end{array}$} \\
\hline ...my relatives. & -0.09 & 0.08 & 0.55 & 0.03 & 0.10 & 2.14 & 1.31 \\
\hline ...my friends. & -0.02 & 0.05 & 0.60 & -0.03 & 0.07 & 2.30 & 1.29 \\
\hline ...faculty members in my department. & 0.14 & 0.10 & 0.81 & 0.01 & 0.21 & 3.06 & 1.37 \\
\hline ...business people. & 0.15 & 0.21 & 0.84 & 0.01 & 0.26 & 3.20 & 1.35 \\
\hline AC ADEMIC PERFORMANCE IN ACCOUNTING (AP) & -0.07 & 0.19 & 0.01 & 1.00 & 0.34 & 41.74 & 18.00 \\
\hline \multicolumn{8}{|l|}{ CAREER INTEREST IN ACCOUNTING (CI) } \\
\hline Think that accounting is very interesting. & 0.17 & 0.43 & 0.22 & 0.29 & 0.84 & 3.48 & 1.33 \\
\hline
\end{tabular}




\begin{tabular}{|l|l|l|l|l|l|l|l|}
\hline $\begin{array}{l}\text { I have an interest in establishing my career in } \\
\text { accounting. }\end{array}$ & 0.07 & 0.42 & 0.22 & 0.34 & $\mathbf{0 . 9 1}$ & 3.20 & 1.36 \\
\hline $\begin{array}{l}\text { I have an interest to pursue my career in accounting as } \\
\text { my lifetime career. }\end{array}$ & 0.09 & 0.39 & 0.23 & 0.29 & $\mathbf{0 . 9 0}$ & 3.06 & 1.34 \\
\hline An accounting career is my first preference. & -0.01 & 0.38 & 0.21 & 0.33 & $\mathbf{0 . 8 8}$ & 2.90 & 1.33 \\
\hline $\begin{array}{l}\text { I have an interest in enrolling in a graduate degree } \\
\text { related to accounting. }\end{array}$ & -0.06 & 0.39 & 0.23 & 0.31 & $\mathbf{0 . 8 0}$ & 2.79 & 1.26 \\
\hline $\begin{array}{l}\text { I have an interest in attending seminars. workshops, } \\
\text { and/or certification programs on accounting. }\end{array}$ & 0.17 & 0.33 & 0.22 & 0.27 & $\mathbf{0 . 8 5}$ & 3.34 & 1.27 \\
\hline $\begin{array}{l}\text { I have an interest in leaming emerging trends and } \\
\text { challenges in accounting. }\end{array}$ & 0.11 & 0.34 & 0.22 & 0.26 & $\mathbf{0 . 7 9}$ & 3.12 & 1.25 \\
\hline $\begin{array}{l}\text { I have an interest in learning new career paths and } \\
\text { opportunities in accounting. }\end{array}$ & 0.14 & 0.34 & 0.22 & 0.22 & $\mathbf{0 . 8 1}$ & 3.25 & 1.27 \\
\hline $\begin{array}{l}\text { I have an interest in awareness about competencies in } \\
\text { accounting profession. }\end{array}$ & 0.08 & 0.22 & 0.14 & 0.19 & $\mathbf{0 . 6 1}$ & 3.86 & 1.12 \\
\hline $\begin{array}{l}\text { I have an interest in acquisition of a more positive } \\
\text { attitude towards accounting profession. }\end{array}$ & 0.15 & 0.31 & 0.19 & 0.16 & $\mathbf{0 . 6 8}$ & 3.74 & 1.22 \\
\hline
\end{tabular}

\section{FINDINGS}

The results from the structural model reported in Figure 2 show that no statistically significant relationship exists between Career Outcome Expectation and Career Interest in Accounting $(\beta=-0.01, p>0.05)$. We also found that Career Challenge $(\beta=0.36, p<0.01)$, Social Influence $(\beta=0.19, p<0.01)$, and Academic Perfomance in Accounting ( $\beta=0.27$, $p<0.01$ ) is positively related to Career Interest in Accounting. $R^{2}$ value is also at an acceptable level (see Figure 2). Therefore, we conclude that Hypothes is 2, Hypothes is 3, and Hypothes is 4 are supported, but Hypothes is 1 is rejected.

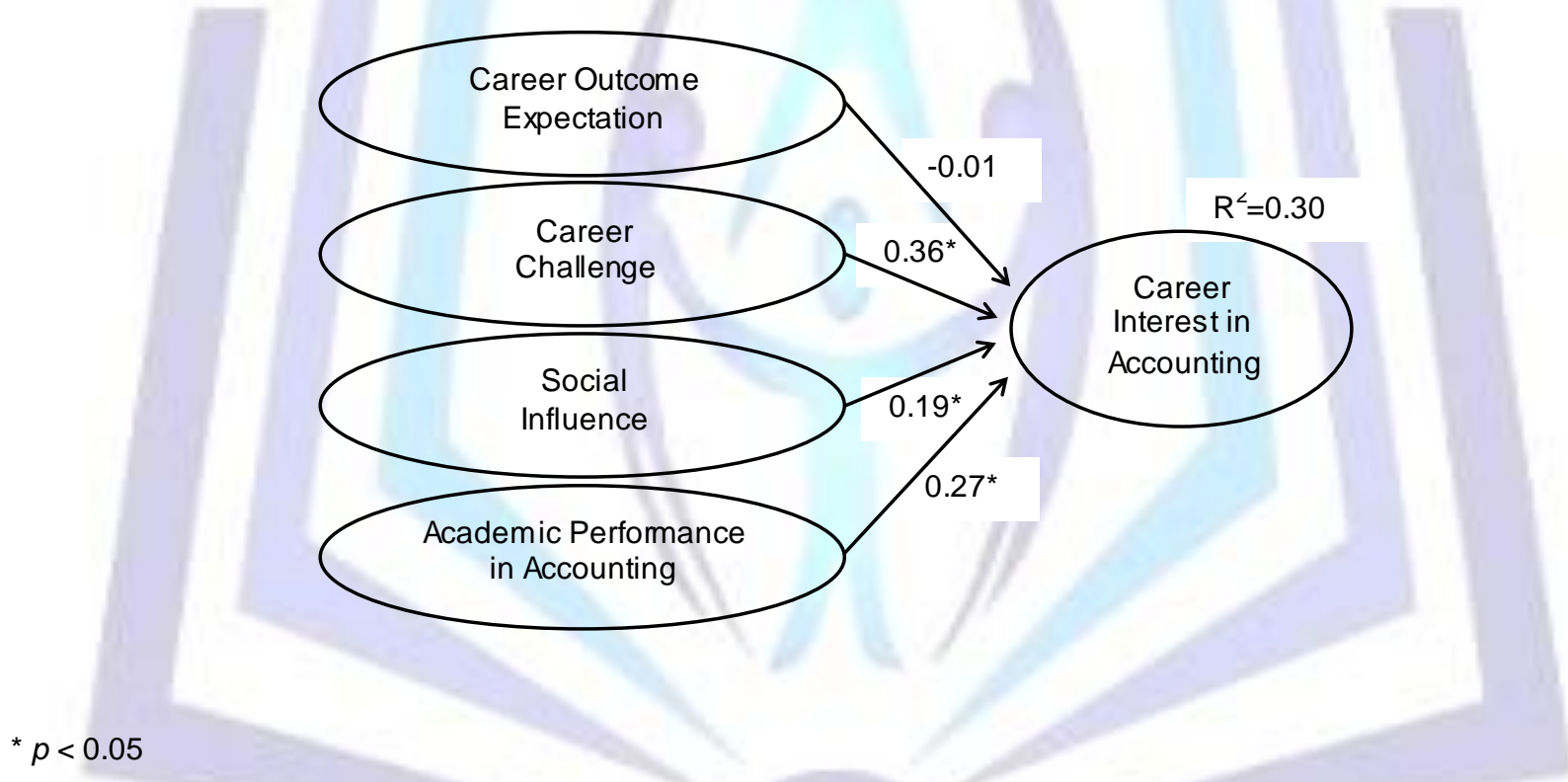

Figure 2. Results from the Structural Model

\section{CONCLUSION}

In this study, the factors that affect the business administration students' career interests in accounting profession were surveyed. A survey was conducted in a total of 250 business administration students who took the Introduction to Accounting course during the Spring 2013 semester at a state university in Turkey. Results of the study indicated that three of the proposed factors affect the career interests of the students in accounting in a positive way. These factors are career challenge, social influence and academic performance in accounting.

Accounting is a profession that requires to work with a lot of numbers and that contains a heavy workload. In addition, the field of accounting is very dynamic due to the impacts of globalization and interconnectedness of the economies, which in turn increases the complexity of the profession. Our findings show that students who like working in such challenging conditions have more interest in the accounting profession. Therefore, a suggestion would be that students and graduates having these qualifications and characteristics should be fostered to arouse an interest in this field.

The prior reserch findings show that students with higher performance in accounting courses they took influence their career decisions in the accounting field. In line with these findings, we found that students who have higher academic performance in accounting have more interest in accounting profession. Thus, students and graduates who are successful 
in their accounting courses should be explained the critical importance of the accounting profession and encouraged to pursue a career in this field.

Finally, our findings reveal that social influence has a positive impact on determining if the students have career interests in accounting. This finding confim the prior research findings as well. However, this should be interpreted with caution, since we have conducted this study in Turkey which possess a collectivistic culture. In collectivistic cultures, there is a tight social framework and the behavior of individuals are influenced and regulated by others (Kongsompong et al., 2009). We would expect that it is likely for people in Turkey (or in any other collectivistic nation) to be influenced by others in their decisions, including the career decisions. Therefore, a new research study with this focus may be conducted to see the global implications of this finding.

\section{REFERENCES}

[1] Ahmed K., Alam K. F., and Alam M. (1997) An empirical study of factors affecting accounting students' career choice in New Zealand, Accounting Education: An International Journal, 6:4, pp. 325-335.

[2] Ajzen, I. (1991) The theory of planned behavior, Organizational Behavior and Human Decision Processes, (50:2), pp. $179-211$.

[3] Allen, C.L. (2004) Business students' perception of the image of accounting, Managerial Auditing Journal, Vol. 19 , No. 2, pp. 235-258.

[4] Auyeung, P. and Sands, J. (1997) Factors influencing accounting students ' career choice: a cross-cultural validation study, Accounting Education: An International Journal, 6(1), pp. 13-23.

[5] Baker, C. R. (1976) An investigation of differences in values: Accounting majors vs. nonaccounting majors, The Accounting Review, Vol. 51, No. 4, pp. 886-893.

[6] Bandura, A. (1997) Self-Efficacy: The Exercise of Control (New York, NY: W.H. Freeman \& Co.).

[7] Bandura, A. (1986) Social Foundations of Thought and Action: A Social Cognitive Theory (Englewood Cliffs, NJ: Prentice-Hall).

[8] Bolhan, D. R., Kassim A., Jonathan, L., and Atan, P. (2007) is accounting profession the right career choice? A case of first year accounting students in Universiti Teknologi Mara Sarawak, Universiti Teknologi Mara, Working Paper, 5 December 2007.

[9] Byrne, D. and Willis, P. (2005) Irish secondary students' perceptions of the work of an accountant and the accounting profession, Accounting Education: An International Joumal, 14(4), pp. 367-381.

[10] Chai, S. (2009) Three Essays On Behavioral Aspects of Information Systems: Issues of Information Assurance and Online Privacy, Doctoral Dissertation, State University Of New York at Buffalo, Buffalo, New York, April 2009.

[11] Churchman, R. J. (2013) Attracting the best and brightest: An examination of the factors that influence students' intent to enter the accounting profession, Doctoral Dissertation, Anderson University, Anderson, Indiana, October 2013.

[12] Cohen, J., and Hanno, D. M. (1993) An analysis of underlying constructs affecting the choice of accounting as a major, Issues in Accounting Education, 8(2), pp. 219.

[13] Felton, S., Dimnik, T. and Northey, M. (1995) A theory of reasoned action model of the chartered accountant career choice, Joumal of Accounting Education, 13(1), pp. 1-19.

[14] Fishbein, M., Ajzen, I. (1975) Belief, Attitude, Intention and Behavior, (Reading, MA: Addison-Wesley).

[15] Heiat, A., Brown, D. and Johnson, D. M. (2007) An empirical analysis of underlying factors affecting the choice of accounting major, Journal of College Teaching \& Learning, Volume 4, Number 8.

[16] Hutaibat, K. A. (2012) Interest in the management accounting profession: Accounting students' perceptions in Jordanian universities, Asian Social Science, Vol. 8, No. 3.

[17] Inman, B. C., Wenzler, A. and Wickert P.D. (1989) Square pegs in round holes: Are accounting students well-suited to today's accounting profession?, Issues in Accounting Education, 4(1), pp. 29-47.

[18] Jackling, B. and Calero, C. (2006) Influences on undergraduate students' intentions to become qualified accountants: Evidence from Australia, Accounting Education: An International Journal, 15:4, pp. 419-438.

[19] Jackling, B., Lange, P.D., Phillips, J. and Sewell, J. (2012) Attitudes towards accounting: Differences between Australian and international students, Accounting Research Joumal, 25(2), pp. 113-130.

[20] Kongsompong, K., Green, R.T., Patterson, P.G. (2009) Collectivism and social influence in the buying decision: A four-country study of inter- and intra-national differences. Australasian Marketing Joumal, 17, pp. $142-149$.

[21] Lent, R.W., Brown, S.D., and Hackett, G. (1994) Toward a unifying social cognitive theory of career and academic interest, choice and performance, Journal of Vocational Behavior, 45, pp. 79-122.

[22] Lent, R.W., Brown, S.D., and Hackett, G. (1996) Career development from a social cognitive perspective, in: D. Brown and Associates (Eds.), Career Choice and Development, 3rd edition, San Francisco, CA: Jossey-Bass.

[23] Lowe, D. R. and Simons, K. (1997) Factors influencing choice of business majors - some additional evidence: a research note, Accounting Education: An International Joumal, 6(1), pp. 39-45.

[24] Mauldin, S., Crain J. L. and Mounce, P. H. (2000) The accounting principles instructor's influence on students' decision to major in accounting, Journal of Education for Business, pp. 142-148.

[25] Mc Dowall, T., Jackling, B. and Natoli, R. (2012) Are we there yet? Changing perceptions of accounting as a career preference", The International Journal of Learning, Volume 18, Issue 4.

[26] Paolillo, J. G. P. and Estes, R. W. (1982) An empirical analysis of career choice factors among accountants, attorneys, engineers and physicians, The Accounting Review, LVII(4), pp. 785-793.

[27] Pritchard R. E., Potter, G. C. and Saccucci, M. S. (2004) The selection of a business major: Elements influencing student choice and implications for outcomes assessment, Journal of Education for Business, 79:3, pp. 152-156.

[28] Ringle, C., Wende, S. and Will, A. (2005) SmartPLS 2.0 (M3) Beta. 
[29] Saemann, G. P. and Crooker, K. J. (1999) Student perceptions of the profession and its effect on decisions to major in accounting", Journal of Accounting Education, 17, pp. 1-22.

[30] Silverstone, R. and Williams, A. (1979) Recruitment, training, employment and careers of women chartered accountants in England and Wales, Accounting and Business Research, 9(33), pp. 105-21.

[31] Schaffner, M. and Jepsen, D. A. (1999) Testing a social cognitive model of career choice development within the context of a minority teacher recruitment program, US Department of Education, Educational Resources Information Center (ERIC), Research Report.

[32] Tan, L. M. and Laswad, F. (2006) Students' beliefs, attitudes and intentions to major in accounting, Accounting Education: An International Journal, 15(2), pp. 167-187.

[33] Yang, F., Mo, L. and Dolar, B.(2012) Early career interest development in accounting: the effect of race after controlling math performance and gender", Accounting and Finance Research, Vol. 1, No. 2.

\section{Authors' biography with Photo}

Dr. Mahmut Yardımcıoğlu is an Associate Professor at Kahramanmaraş Sütçü Imam University, Turkey. He received Master's degree in Business Administration from Kahramanmaraş Sütçü Imam University, Turkey, and Ph.D. degree from Selçuk University.

Şebnem Ada is a lecturer at Selçuk University, Turkey. She received BS degree in Business Administration from Celal Bayar University, Turkey in 2003, Master's degree in Business Administration from Celal Bayar University, Turkey in 2006. She is currently a Ph.D. candidate at the Kahramanmaraş Sütçü Imam University, Turkey. 